\title{
ADHERENCE TO METHADONE MAINTENANCE TREATMENT (MMT) AND ITS RELATED FACTORS IN WEST JAVA, INDONESIA
}

\author{
Anggita Bunga Anggraini* \\ National Institute of Health Research and Development, Ministry of Health, Indonesia
}

\begin{abstract}
Injecting Drug Users (IDUs) is one of the leading causes of Human Immunodeficiency Virus (HIV) epidemic in several countries in Asia. To anticipate the danger posed by the transmission of HIV and to reduce opioid injection, the Methadone Maintenance Treatment was developed. Adherence to Methadone Maintenance Treatment (MMT) is one of the evaluation criteria in MMT because it requires a long period of therapy. Adherence patterns and related factors are important to achieve treatment goals. This study aims to identify several factors related to MMT adherence in West Java, Indonesia. This cross-sectional study was carried out to 92 participants from three selected primary health care which conducted the MMT program in West Java in 2018. Data was collected from patients interviews, methadone retrieval records from the last 30 days, and medical records from April- June 2018. Patient characteristics and other variables were analyzed using descriptive statistics. For bivariate analysis, Chi-square test was used to select related factors to patient's adherence. Multiple linear regression with stepwise method was used to analyze dominant factors related to patient adherence. This study found a total of $58.7 \%$ of participants were deemed adherent to MMT. Besides, patients that had a diagnose of HIV positive [adjusted odds ratio (ORa) = $4.03 ; \mathrm{P}=0.005]$ and surrounded by somebody with which patients can share their life (ORa $=6.26$; $\mathrm{P}=0.005$ ) may lead to higher adherence. Adherence to MMT was associated with several factors. To improve patient adherence, support from family and friends are substantial. Meanwhile, patients with a history of negative HIV must be monitored to sustain its adherence to MMT program.
\end{abstract}

Keywords: adherence, methadone treatment, West Java

\section{Introduction}

Drug abuse has become one of the global burden diseases. It caused loss productivity by the Disability Adjusted Life Years (DALYs) in 2015 amounting to 17 million or $0.66 \%$ of the overall causes of the world burden. While the mortality rate was 2.3 per 100,000 population or accounts for $0.2 \%$ of the total DALYs (WHO, 2017). Based on World Drug Report in 2016, there were 247 million people using drug worldwide. As many as 29 million drug users suffer from drug use disorder involving Injecting Drug Users (IDUs).Around 12 million with a total of $14 \%$ of IDUs living with HIV (UNODC, 2016).

IDUs is one of leading cause of Human Immunodeficiency Virus (HIV) epidemic in several countries in Asia. This virus is transmitted when IDUs share syringes that had contaminated with HIV-infected blood (WHO, 2009).

To anticipate the danger posed by the transmission of HIV and to reduce opioid injection, the Methadone Maintenance Treatment was developed. Methadone is one of the drugs that is included in the World Health Organization (WHO) essential drugs lists because it diverts chronic dependence of injectable opioids, preventing transmission of HIV, Hepatitis B and C from shared needles (WHO, 2009). Introduction to MMT in Indonesia began in 2006 after the Ministry of Health and WHO conducted clinical trials in several hospitals in Indonesia in 2003 (Universitas Katolik Atma Jaya \& Kementerian Kesehatan RI, 2015). 
MMT needs high adherence and it becomes one of the criteria that must be assessed every month. Many patients do not adhere to treatment. Withdrawal can inhibit patients' recovery in social aspects and health (Kementerian Kesehatan, 2013; Pratiwi, 2012). In Indonesia, the level of MMT adherence were varied. In 2011, the adherence rate only 67.4\% in Manahan Primary Health Care, Solo, while in Cibubur Hospital in 2013 amounted to 62.7\% (Budiyani, 2013; Rodiyah, 2011). Study in Malaysia showed that low adherence was associated with age, low quality of life, unemployment, and low methadone dose (Ramli, A Zafri, Junid, \& Hatta, 2012; Sharifa Ezat et al., 2009)

Data from the Ministry of Health, Republic of Indonesia in June 2010showed that the highest prevalence of IDUs was Jakarta, West Java, and East Java. Based on the regulation issued by the Ministry of Health in 2013, there are five selected primary health care that implement MMT program in West Java which were located in Bekasi, Bogor, Depok, and Subang (Kementerian Kesehatan, 2013). Adherence to MMT is important for the patient's recovery, so it is necessary to determine factors contribute to MMT adherence that could improve a treatment. This study is carried out involving primary health care in West Java.

\section{Method}

This is a cross-sectional study that was conducted in purposive selected three primary health care that deliver MMT program in Depok and Bogor, West Java inIndonesia. These cities were chosen because they are located not far from the capital city of Indonesia and considered big city.

The sample was determined using the hypothesis test for two population proportions as seen below (Lachenbruch, Lwanga, \& Lemeshow, 1991):

$$
n=\left[\frac{Z_{1-\alpha / 2} \sqrt{2 P(1-P)}+Z_{1-\beta} \sqrt{P 1(1-P 1)+P 2(1-P 2)}}{(P 1-P 2)^{2}}\right]^{2}
$$

Where;

$\mathrm{n} \quad=$ sample size

$\alpha=$ level of significance (95\% level of confidence, $Z$ value is 1.96 )

$1-\beta=$ power of test $(80 \%$ power, $\mathrm{Z}$ value is 0.84$)$

P1 = anticipated population proportion 1 (non-adherent population was 15.3\%) (Universitas Katolik Atma Jaya \& Kementerian Kesehatan RI, 2015)

$\mathrm{P} 2=$ anticipated population proportion 2 (adherent population was assumed as 50\%)

The calculation suggests the minimum sample size for each group is 27.5 which is rounded up to 28 subjects and thus the total subjects is 56 .

The sample must meet inclusion and exclusion criteria. Inclusion criteria is an adult (of minimum 18 years old), have already joined MMT program at least 1 month, and able to communicate. Exclusion criteria were patients with loss of consciousness, could not cooperate, referral patients who only join MMT program temporaryly, and decline to join the study.

Data was obtained from patient medical records and interview using structured questionnaire from April-June 2018. The subjects who agreed to participate signed an informed consent form and fill out a questionnaire. Data on adherence were obtained from medication retrieval records in April 2018 from primary health care. The data 
were guaranteed of anonymity and confidentiality. Data being collected include subject characteristics, history of HIV, history of methadone treatment, and social support. For this analysis, adherence was defined as a client who did not miss single dose of methadone in a month. Adherence was divided into 2 categories (non-adherent and adherent).

Sex was categorized into male and female. Age is classified into 2 groups ( $<35$ years and $35-56$ years). Marital status was divided into single, married, divorced/widowed). Patients' occupation was categorized into 2 categories (unemployed and employed).

Methadone dose is a dose of methadone obtained at this time. It was divided into $<60 \mathrm{mg}$ and $\geq 60 \mathrm{mg}$. Duration of methadone treatment was assessed by asking subjects how long they have joined methadone counting since the first intake until the time of survey. It was categorized into 3 categories (1-64 months, 65-112 months, and 113-208 months). History of HIV was classified into 2 groups (negative and positive). Social support was evaluated by 2 questions: the presence of a person that patients can share their life with and a person who willing to lend/give money when patients asked. These questions categorized into yes and no.

A total of 92 subjects were obtained from three primary health care. Patient characteristics and other variables were analyzed using descriptive statistics. For bivariate analysis, Chi-square test was used to select related factors to patient's adherence. Multiple linear regression with stepwise method was used to analyze dominant factors related to patient adherence. The data were analyzed using Statistical Package for Social Sciences (SPSS).

Ethical approval for this study was obtained from the Ethics Committee of Faculty of Public Health Universitas Indonesia. Before conducting the study, permission from relevant authorities in connection with this study was sought. The District Health Office of Bogor and Depok, West Java have approved study undertaking.

\section{Results}

Table 1 showed the subject characteristics. The total subjects that meet criteria were 92 patients. Overall, the prevalence of patients who adhere to the treatment was $58.6 \%$ or 54 adherence patience out of the total 92 subjects. Among $89.1 \%$ of subjects were male and most of the subject (83.6\%) were 35-56 years old. Approximately $65.2 \%$ of subjects were married, while $82.6 \%$ were employed. Most of the subjects received methadone dose of more than or equal to $60 \mathrm{mg}$ per day, while $40.2 \%$ of subjects received $65-112$ months of therapy. 
Table 1 Several Demographic Factors and Risk of Adherence to MMT

\begin{tabular}{|c|c|c|c|c|c|c|c|}
\hline & \multicolumn{4}{|c|}{ Adherence } & \multirow{3}{*}{$\begin{array}{l}\text { Crude } \\
\text { Odd } \\
\text { Ratio }\end{array}$} & \multirow{3}{*}{$\begin{array}{l}95 \% \\
\text { confidence } \\
\text { interval }\end{array}$} & \multirow[b]{3}{*}{$\mathrm{P}$} \\
\hline & \multicolumn{2}{|c|}{$\begin{array}{l}\text { Non-adherent } \\
(\mathrm{n}=38)\end{array}$} & \multicolumn{2}{|c|}{$\begin{array}{l}\text { Adherent } \\
(\mathrm{n}=54)\end{array}$} & & & \\
\hline & $\mathrm{n}$ & $\%$ & $\mathrm{n}$ & $\%$ & & & \\
\hline \multicolumn{8}{|l|}{ Sex } \\
\hline Male & 33 & 40.2 & 49 & 59.8 & 1.00 & Reference & \\
\hline Female & 5 & 50.0 & 5 & 50.0 & 0.67 & $0.18-2.51$ & 0.557 \\
\hline \multicolumn{8}{|l|}{ Age group } \\
\hline$<35$ years & 6 & 40.0 & 9 & 60.0 & 1.00 & Reference & \\
\hline $35-56$ years & 32 & 41.6 & 45 & 58.4 & 0.94 & $0.30-2.90$ & 0.911 \\
\hline \multicolumn{8}{|l|}{ Marital status } \\
\hline Single & 6 & 31.6 & 13 & 68.4 & 1.00 & Reference & \\
\hline Married & 24 & 40.0 & 36 & 60.0 & 0.69 & $0.23-2.07$ & 0.511 \\
\hline Divorced/widowed & 8 & 61.5 & 5 & 38.5 & 0.29 & $0.07-1.27$ & 0.099 \\
\hline \multicolumn{8}{|l|}{ Occupation } \\
\hline Unemployed & 8 & 50.0 & 8 & 50.0 & 1.00 & Reference & \\
\hline Employed & 30 & 39.5 & 46 & 60.5 & 1.53 & $0.52-4.53$ & 0.437 \\
\hline \multicolumn{8}{|l|}{ Dosage } \\
\hline$<60 \mathrm{mg}$ & 15 & 40.5 & 22 & 59.5 & 1.00 & Reference & \\
\hline$\geq 60 \mathrm{mg}$ & 23 & 41.8 & 32 & 58.2 & 0.95 & $0.41-2.21$ & 0.903 \\
\hline \multicolumn{8}{|c|}{ Duration of methadone treatment } \\
\hline 1-64 months & 17 & 50.0 & 17 & 50.0 & 1.00 & Reference & \\
\hline 65-112 months & 12 & 32.4 & 25 & 67.6 & 0.75 & $0.25-2.24$ & 0.607 \\
\hline 113-208 months & 9 & 42.9 & 12 & 57.1 & 1.56 & $0.52-4.72$ & 0.429 \\
\hline \multicolumn{8}{|l|}{ History of HIV } \\
\hline Negative & 27 & 52.9 & 24 & 47.1 & 1.00 & Reference & \\
\hline Positive & 11 & 26.8 & 30 & 73.2 & 3.07 & $1.27-7.42$ & 0.011 \\
\hline \multicolumn{8}{|c|}{ Surrounded by somebody with which patients can share their life } \\
\hline No & 12 & 70.6 & 5 & 29.4 & 1.00 & Reference & \\
\hline Yes & 26 & 34.7 & 49 & 65.3 & 4.52 & $1.44-14.24$ & 0.007 \\
\hline \multicolumn{8}{|c|}{ Presence of person who will lend/give money if needed } \\
\hline No & 4 & 25.0 & 12 & 75.0 & 1.00 & Reference & \\
\hline Yes & 34 & 44.7 & 42 & 55.3 & 0.41 & $0.12-1.40$ & 0.135 \\
\hline
\end{tabular}

Table 2 showed that compared to subjects who had a history of negative HIV, subjects who had a history of positive HIV had 4 times higher chance to adhere to the treatment [adjusted odds ratio $(\mathrm{ORa})=4.03 ; \mathrm{p}=0.005$ ]. Meanwhile, surrounded by somebody with which patients can share their life had a higher chance to improve patients' adherence $(\mathrm{ORa}=6.26 ; \mathrm{p}=0.005)$. 
Table 2: Dominant Factors Related to MMT Adherence

\begin{tabular}{|c|c|c|c|c|c|c|c|}
\hline & \multicolumn{4}{|c|}{ Adherence } & \multirow{3}{*}{$\begin{array}{l}\text { Adjusted } \\
\text { Odd } \\
\text { Ratio }\end{array}$} & \multirow{3}{*}{$\begin{array}{l}95 \% \\
\text { Confidence } \\
\text { interval }\end{array}$} & \multirow{3}{*}{$\mathrm{P}$} \\
\hline & \multicolumn{2}{|c|}{$\begin{array}{l}\text { Non-adherent } \\
(\mathrm{n}=38)\end{array}$} & \multicolumn{2}{|c|}{$\begin{array}{l}\text { Adherent } \\
(\mathrm{n}=54)\end{array}$} & & & \\
\hline & $\mathrm{n}$ & $\%$ & $\mathrm{n}$ & $\%$ & & & \\
\hline \multicolumn{8}{|c|}{ History of HIV } \\
\hline Negative & 27 & 52.9 & 24 & 47.1 & 1.00 & Reference & \\
\hline Positive & 11 & 26.8 & 30 & 73.2 & 4.03 & $1.51-10.75$ & 0.005 \\
\hline \multicolumn{8}{|c|}{ Surrounded by somebody with which patients can share their life } \\
\hline No & 12 & 70.6 & 5 & 29.4 & 1.00 & Reference & \\
\hline Yes & 26 & 34.7 & 49 & 65.3 & 6.26 & $1.79-21.96$ & 0.005 \\
\hline
\end{tabular}

\section{Discussion}

This study showed that $58.7 \%$ of MMT clients adhered to the treatment which seems to be higher than similar studies in Iran which only revealed 21.8\% of clients had good adherence to MMT (Nabavi \& Ahmadipour, 2018). A study in Malaysia showed $86.1 \%$ of clients adhered to the treatment (Sharifa Ezat et al., 2009). This number showed that MMT primary health care in West Java need to improve the effectiveness of treatment. One way to do it is intensifying non-pharmacological interventions such as group motivational (Nabavi \& Ahmadipour, 2018; Navidian, Kermansaravi, Tabas, \& Saeedinezhad, 2016)

Poor adherence to MMT increases the risk of drug withdrawal symptoms, relapse of medication, and overdose due to loss of tolerance (Greenwald, 2002; Wolff, 2002). Meanwhile, data on patient adherence can be used to control the quality of MMT services and indicators for drug allocation (Nguyen, Nguyen, Nguyen, Tran, \& Latkin, 2017).

Patients with a history of positive HIV are more likely to adher with MMT. Compliance to therapeutic regimens in HIV patients is driven by a greater sense of trust and security to health care providers. It is associated consistently with MMT (Spire, Lucas, \& Carrieri, 2007).

Presence of someone who will support had a positive association with patient adherence. Social support is important to increase participation in therapy, such as families that can assist to remind client to take medication that can increase a sense of stability (Lin, Wu, \& Detels, 2011; Nguyen et al., 2017). Social support is correlated to clients' quality of life (Yen, Chou, Lin, \& Deng, 2015). A study in 2011 also showed that having at least one friend could generate positive to the quality of life (De Maeyer et al., 2011). Combining social support into the MMT program is highly recommended to increase life satisfaction and treatment outcomes (Yen et al., 2015). Support of family and involving dear friend to clients can help them keep track with the medication. Financial support is necessary because methadone is not available for free.

Regarding Guideline for Implementing MMT Program in Indonesia, adherence becomes one of the criteria to assess treatment outcomes, but the definition of adherence and level of adherence are not explained in detail. In Vietnam, assessment of adherence was carried out using standards from Ministry of Health of Vietnam by asking 3 main questions: (1) the number of days they missed the dose in last 4 days; (2) whether they missed doses in past week; (3) whether they missed the dose in last 3 months. Adherence is assessed optimally if the clients reports "no" for these three questions, and suboptimal if they answer "yes" or "don't remember" on any question (Nguyen et al., 2017). In Malaysia, non-adherent is defined when a patient missed the treatment for two 
weeks or more, but if the same patient returns to treatment for two weeks later, these patients will be regrouped as adherent (Ramli et al., 2012). In Indonesia, patients are declared as drop-out if they stop taking methadone for 7 consecutive days and without any information of their existence. In this condition, the doctor must re-assess if they want to go back to the therapy (Kementerian Kesehatan, 2013).

This study had several limitations that should be considered. The research only conducted in three primary health care in West Java, so it did not represent hospitals that implement MMT in West Java. Assessment of clients' adherence was based on drug retrieval record in primary health care, therefore researchers could not ascertain whether the clients took the medicine. Sometimes clients could not administered the medicine for several reasons such as spiling or vomiting. These cases become challenges for primary health care in Indonesia to ensure client adherence to the treatment. MMT personnel need to pay attention to observe changes in the client's behaviour.

\section{Conclusion}

In conclusion, an adherence to MMT associates with patient's history to HIV test and the availability of someone to provide support and care. To improve patient adherence, support from family and friends are significant. Combining social support programs into the MMT program is highly recommended to increase treatment outcomes. Meanwhile, patients with a history of negative HIV must be monitored to sustain its adherence to the MMT program.

\section{Acknowledgments}

The author wishes to express the sincerest gratitude to the Chiefs of Bogor and Depok Health Offices and Chief of primary health care for providing the data and research permit.

\section{References}

Budiyani, P. I. R. (2013). Faktor-Faktor yang Berhubungan dengan Ketidakpatuhan pada Pengguna Narkotika, Psikotropika, dan Zat Adiktif (NAPZA) Suntik yang Mengikuti Program Terapi Rumatan Metadon di Rumah Sakit Ketergantungan Obat Cibubur Jakarta Timur Tahun 2013. Universitas Indonesia.

De Maeyer, J., Vanderplasschen, W., Lammertyn, J., Nieuwenhuizen, C. Van, Sabbe, B., \& Broekaert, E. (2011). Current quality of life and its determinants among opiate-dependent individuals five years after starting methadone treatment. Quality of Life Research, 20, 139-150. https://doi.org/10.1007/s11136-010-9732-3

Greenwald, M. K. (2002). Heroin craving and drug use in opioid-maintained volunteers: effects of methadone dose variations. Experimental and Clinical Psychopharmacology, 10(1), 39-46. Retrieved from http://www.ncbi.nlm.nih.gov/pubmed/11866251

Kementerian Kesehatan. Peraturan Menteri Kesehatan Republik Indonesia Nomor 57 Tahun 2013 Tentang Pedoman Penyelenggaraan Program terapi Rumatan Metadona, Pub. L. No. 57 (2013). Indonesia.

Lachenbruch, P. A., Lwanga, S. K., \& Lemeshow, S. (1991). Sample Size Determination in Health Studies: A Practical Manual. Journal of the American Statistical Association. https://doi.org/10.2307/2290547

Lin, C., Wu, Z., \& Detels, R. (2011). Family support, quality of life and concurrent substance use among methadone maintenance therapy clients in China. Public Health, 125(5), 269-274. https://doi.org/10.1016/j.puhe.2011.01.009

Nabavi, S. H., \& Ahmadipour, H. (2018). Adherence to Methadone Maintenance Treatment and its Predictors in Southeast of Iran, 6(1), 1-4. https://doi.org/10.19080/GJARM.2018.06.555680

Navidian, A., Kermansaravi, F., Tabas, E. E., \& Saeedinezhad, F. (2016). Efficacy of Group Motivational Interviewing in the Degree of Drug Craving in the Addicts Under the Methadone Maintenance Treatment 
(MMT) in South East of Iran. Archives of Psychiatric Nursing, 30(2), 144-149. https://doi.org/10.1016/j.apnu.2015.08.002

Nguyen, L. H., Nguyen, H. T. T., Nguyen, H. L. T., Tran, B. X., \& Latkin, C. A. (2017). Adherence to methadone maintenance treatment and associated factors among patients in Vietnamese mountainside areas. Substance Abuse: Treatment, Prevention, and Policy, 12(1), 1-9. https://doi.org/10.1186/s13011-017-0115-4

Pratiwi, E. Y. (2012). Dukungan Keluarga Terhadap Kepatuhan Menjalankan Program Terapi pada Pasien Terapi Rumatan Metadon. Developmental and Clinical Psychology, 1(1), 57-62.

Ramli, M., A Zafri, A. B., Junid, M. R., \& Hatta, S. (2012). Associated risk factors to Non-compliance to Methadone Maintenance Therapy. Med J Malaysia, 67(6). Retrieved from http://www.emjm.org/2012/v67n6/methadone-maintenance-therapy.pdf

Rodiyah, K. (2011). Analisis Faktor-Faktor yang Berhubungan dengan Kepatuhan Terapi Rumatan Metadon Pada Pengguna NAPZA Suntik (Studi di Puskesmas Manahan Kota Surakarta Tahun 2011). Universitas Negeri Semarang.

Sharifa Ezat, W. P., Noor Azimah, H., Rushidi, R., Raminder, K., \& Ruhani, I. (2009). Compliance Towards Methadone Maintenance Therapy and its Associated Factors in Selangor Primary Care Centers and Kuala Lumpur Hospital.

Spire, B., Lucas, G. M., \& Carrieri, M. P. (2007). Adherence to HIV treatment among IDUs and the role of opioid substitution treatment (OST). International Journal of Drug Policy, 18(4), $262-270$. https://doi.org/10.1016/j.drugpo.2006.12.014

Universitas Katolik Atma Jaya, \& Kementerian Kesehatan RI. (2015). Laporan Penelitian Operasional: Evaluasi dan intervensi Pengobatan Terapi Rumatan Metadon (PTRM). Jakarta. Retrieved from https://media.neliti.com/media/publications/45305-ID-penelitian-operasional-evaluasi-dan-intervensipengobatan-terapi-rumatan-metadon.pdf

UNODC. (2016). World Drug Report 2016. Vienna: United Nations Office on Drugs and Crime.

WHO. (2009). Clinical Guidelines For Withdrawal Management and Treatment of Drug Dependence in Closed Setting. Geneva: WHO Press.

WHO. (2017). Alcohol and drug use disorders: Global Health Estimates. Geneva. Retrieved from http://www.who.int/substance_abuse/activities/fadab/msb_adab_2017_GHE_23June2017.pdf

Wolff, K. (2002). Characterization of methadone overdose: Clinical considerations and the scientific evidence. Therapeutic Drug Monitoring, 24(4), 457-470. https://doi.org/10.1097/00007691-200208000-00001

Yen, Y. F., Chou, P., Lin, Y. S., \& Deng, C. Y. (2015). Factors associated with health-related quality of life among injection drug users at methadone clinics in Taipei, Taiwan. Journal of the Chinese Medical Association, 78(5), 292-298. https://doi.org/10.1016/j.jcma.2015.01.001 